entomological work ever produced," "Rippon's monograph on bird-wing butterflies (1898-1906), of which not more than thirty copies were completed, and Dresser and Sharpe's history of the birds of Europe (1871-1896). The most notable works on medicine and surgery in the catalogue are the first quarto edition of Sir Thomas Elyot's "Castel of Helth" (1541), the first edition of Gerard's "Herball or Generall Historie of Plantes" (1597) and the first edition of Harvey's "De Motu Cordis" (1628). A mong the old works on the exact and applied sciences figure the first edition of Cocker's "Arithmetik" (1678), Billingsley's translation of Euclid's 'Elements of Geometrie" (1570), Watson's translation of Bernard Palissy's "Learned Dialogue Concerning Waters and Fountaines" and Zahn's work on contemporary optics (1702).

\section{Speed Records}

ON September 15, the world's speed record on land was raised to $350 \cdot 2$ m.p.h. by Mr. John Cobb at the Bonneville Salt Flats, Utah. The car used was a 2,500 h.p. Napier-Railton. The previous record was $345 \cdot 59$ m.p.h. set up by Captain G. E. T. Eyston in his car Thunderbolt (see NATURe, Sept. 3, p. 430). On September 16, Captain Eyston regained the world record from Mr. Cobb with the Thunderbolt, attaining an average speed of 357.5 m.p.h. Sir Malcolm Campbell set up a water speed record of 130.91 m.p.h. on September 17 at Lake Hallwil, Switzerland, in his motor-boat Bluebird.

\section{North-East Coast Institution Engineering Awards}

THE Gold Medals of the North East-Coast Institution of Engineers and Shipbuilders given for papers read during the session have been awarded as follows : Engineering Gold Medal to G. J. Lugt, of the Werkspoor Company, Amsterdam, for his paper on "Diesel Varia"; Shipbuilding Gold Medal to Prof. F. Horn, of the Technische Hochschule, Berlin, for his paper on "Measurement of Wake"; M. C. James Gold Medal to Dr. T. Swinden for his paper on "Special Steels and their Application to Engineering and Shipbuilding". The Thomas Fenwick Reed Gold Medal, for the member of the Institution not more than thirty years of age who, among entrants for the medal, shows the greatest evidence of ability to take a share in the control of industry, has been awarded to John Hindmarsh. Mr. Hindmarsh was for some time in the employment of Michell Bearings, Ltd., before obtaining his Whitworth Scholarship, when he went to King's College, London; he is now employed by Messrs. Swan, Hunter and Wigham Richardson, Ltd., Neptune Works, Walker, Newcastle-on-Tyne. The Institution is giving two new scholarships this session (each of $£ 100$ ). These have been awarded to Harry Chilton, an apprentice of the North-Eastern Marine Engineering Co. (1938), Ltd., and a student at Sunderland Technical College ; and Thomas Corin, an apprentice ship draughtsman in the employment of Messrs. Swan, Hunter and Wigham Richardson, Ltd., Wallsend-on-Tyne, for study at King's College, Newcastle-on-Tyne.

\section{Announcements}

DURING the forthcoming winter, Mr. H. V. Garner, the guide demonstrator of the Rothamsted Experimental Station, and other members of the staff, will be available for lectures on the Rothamsted experiments to agricultural societies and similar bodies. All communications regarding lectures should be addressed to the Secretary, Rothamsted Experimental Station, Harpenden, Herts.

Prof. Alfred KÜHN, director of the KaiserWilhelm Institute of Biology, Berlin, Dr. Hugo Hassingen, professor of geography at the University of Vienna, and Dr. Hans Ahlmann, professor of geography at Stockholm, have been elected members of the Prussian Academy of Sciences in the physico. mathematical class.

The Child Welfare Information Centre of the League of Nations has issued a useful analysis of reports received by the Secretariat from thirty-seven countries on the legislative and administrative measures that have been taken or have been under consideration during the year May 1937 to May 1938 with reference to any aspect of child welfare (London: Allen and Unwin. 3s.).

The Child Guidance Council has awarded fellowships in psychiatry of the value of $£ 300$ and tenable for a year to Drs. Allen G. Crisp, Kenneth Soddy and Rosalind Vacher for half-time work at the London Child Guidance Clinic, 1 Canonbury Place, Islington, N.1.

The New York banker, Mr. W. Childs, has left Yale University ten million dollars for cancer research.

THIRTY radio coast stations of the United States are provided with a medical man to give advice to passing ships.

THE London County Council has accepted a tender for $£ 72,135$ for building work in connexion with the erection of its new antitoxin establishment at Carshalton, which will afford valuable opportunities for research.

THE Ministry of Health with the collaboration of the Department of Health for Scotland and the National Fitness Council has arranged a permanent Health Exhibition which is being shown at the British Empire Exhibition and will be sent on to towns throughout Great Britain.

THE sixth Argentine Congress of Medicine, which will be held at Cordoba on Oetober 16-21, will consist of three sections devoted respectively to biology, internal medicine and surgery.

ThE twenty-fifth French Congress of Social Hygiene will be held at the Bordeaux Faculty of Medicine on September 30-October 2 under the presidency of M. Georges Risler. Further information can be obtained from Alliance d'hygiène sociale, 5 rue des Cases, Paris. 